Western North American Naturalist 70(1), (C) 2010, pp. 77-91

\title{
BIOTIC AND ABIOTIC FACTORS RELATED TO REDBAND TROUT OCCURRENCE AND ABUNDANCE IN DESERT AND MONTANE STREAMS
}

\author{
Kevin A. Meyer ${ }^{1,2}$, James A. Lamansky Jr. ${ }^{1}$, and Daniel J. Schill ${ }^{1}$
}

\begin{abstract}
Redband trout Oncorhynchus mykiss gairdneri in the Columbia River Basin of western North America occupy desert and montane streams with variable habitat conditions. In general, desert streams are lower in gradient and elevation, contain less large substrate and more silt substrate, are less shaded by overhead vegetation, and have higher summer water temperature than montane streams. Consequently, we assessed whether the relationships between biotic and abiotic factors and the occurrence and abundance of redband trout in southwestern Idaho differed between desert and montane streams $(<25 \mathrm{~m}$ mean width). Increased occurrence of redband trout in desert streams was most strongly related to increased stream shading and decreased amounts of silt substrate, followed by increased amounts of cobble/boulder substrate and absence of piscivorous fish (i.e., smallmouth bass Micropterus dolomieui and northern pikeminnow Ptychocheilus oregonensis). In montane streams, increased occurrence of redband trout was most strongly related to decreased site elevation and increases in cobble/boulder substrate, followed by decreases in stream gradient and width. Furthermore, occurrence of redband trout decreased in desert streams at mean summer (June-August) water temperature $\left(\mathrm{Temp}_{\mathrm{smr}}\right)>16{ }^{\circ} \mathrm{C}$, whereas for montane streams, occurrence increased at $\mathrm{Temp}_{\mathrm{smr}}>9$ ${ }^{\circ} \mathrm{C}$. Redband trout density in desert streams was most strongly related to higher stream order (i.e., headwater streams), increased stream shading, and increased amounts of cobble/boulder substrate. In montane streams, redband trout density was not well explained by any stream conditions, but stream shading had the strongest positive relationship with density. Redband trout density was negatively related to $\mathrm{Temp}_{\mathrm{smr}}$ in desert streams, but the relationship was weak for montane streams. That environmental conditions related to the occurrence and abundance of redband trout differ between desert and montane streams is important for fisheries managers who manage these disparate populations occurring in such close proximity to each other.
\end{abstract}

Key words: redband trout, desert streams, montane streams, temperature, fish-habitat relationships.

Redband trout Oncorhynchus mykiss gairdneri are native to much of the Columbia River Basin east of the Cascade Range in western North America. This species occupies a variety of habitats from small streams to large rivers and lakes and includes anadromous and nonanadromous (i.e., resident) forms. Stream-dwelling forms live in a variety of habitats, ranging from high-desert streams in arid landscapes to forested montane streams. Their evolution in such a wide range of environmental conditions may help explain why redband trout remain the most widely distributed native salmonid in the Columbia River Basin (Thurow et al. 1997). Nevertheless, the species has declined in occurrence and abundance (Thurow et al. 1997), due largely to hybridization with nonnative salmonids and anthropogenic disturbance resulting in habitat fragmentation, alteration, and desiccation. Such declines led to a petition in 1995 to list redband trout in the Snake River Basin, the largest tributary of the Columbia River, for protection under the Endangered Species Act of the United States; but the petition was deemed unwarranted at that time (USOFR 1995).

In the interior Columbia River Basin, numerous studies have been conducted at several spatial scales on the habitat preferences of redband/rainbow trout in streams. In montane streams, redband trout presence has been positively related to the abundance of pools and negatively related to stream gradient (Muhlfeld et al. 2001a), whereas in desert streams, redband trout presence has been associated more closely with shaded reaches of stream that allow less solar radiation and produce cooler stream temperatures ( $\mathrm{Li}$ et al. 1994, Zoellick 1999, 2004). In a cursory comparison of these 2 settings, Platts and Nelson (1989) found that 
thermal input was a much better predictor of salmonid biomass in Great Basin desert streams than in Rocky Mountain montane streams, but generalizations that can be drawn from this study are limited because a number of salmonid species (including redband trout) were included, each with unique habitat preferences. Moreover, sample sizes have been limited in most of the aforementioned studies on redband trout habitat preferences, rendering it difficult to fully describe the relationship between environmental conditions and redband trout abundance in desert and montane settings.

Establishing any relationship between stream-dwelling fish and their environment is often problematic because studies are usually focused at small scales (e.g., McFadden and Cooper 1962, Binns 1982, Chisholm and Hubert 1986, Kozel and Hubert 1989). Thus they tend to lack generality because sample sizes are often insufficient to fully characterize relationships, or the limited study area is not necessarily representative of other areas of a species' range (Fausch et al. 1988). Moreover, a single environmental condition is often not the only limiting factor for a population (Terrell et al. 1996), and the influence of environmental conditions on ecological response variables is often not linear (Huston 2002). Huston (2002) listed 3 primary obstacles to developing models that accurately conceptualize relations between ecological patterns and the factors that produce them. These obstacles include (1) mismatches between spatial and temporal dimensions of ecological measurement and the dimensions at which hypothesized processes operate, (2) misunderstanding of ecological processes, and (3) inappropriate statistics used to quantify ecological patterns and processes.

Southwestern Idaho offers a unique opportunity to more fully assess the relationships between stream habitat conditions and redband trout occurrence and abundance in desert and montane streams that are in close proximity. The objectives of this study were (1) to assess, at several spatial scales, the biotic and abiotic stream conditions most strongly related to redband trout metrics and (2) to determine whether the same or different parameters appeared to be important in desert and montane environments. Our large, spatially balanced sample size over a broad spatial range circumvented some of the limitations often inherent in studies of fish-habitat relationships.

\section{Study AREA}

The Snake River flows $1674 \mathrm{~km}$ east to west from its headwaters in Yellowstone National Park to its confluence with the Columbia River, crossing through southern Idaho. The 83,892$\mathrm{km}^{2}$ study area (Fig. 1) included nearly all tributaries of the Snake River from Hell's Canyon Dam along the Oregon-Idaho border upstream to Shoshone Falls-a 65-m natural waterfall that halted upstream colonization by redband trout. We excluded the Burnt River, Powder River, Malheur River, and Pine Creek drainages in Oregon because they lie entirely outside of Idaho and our management jurisdiction. Discharge in much of the study area is heavily influenced by snowmelt and peaks between April and June. Elevation within the basin ranges from $514 \mathrm{~m}$ at Hell's Canyon Dam to $3600 \mathrm{~m}$ at mountain peaks.

The historical range of redband trout in Idaho included all of the Snake River and its tributaries below Shoshone Falls, except the Coeur d'Alene River drainage in northern Idaho (Behnke 2002). Chinook salmon O. tshawytscha, sockeye salmon $O$. nerka, and steelhead trout (the anadromous form of O. mykiss) were native to the study area but were denied upstream access in the Snake River and its tributaries by the construction of a series of dams, beginning with Swan Falls Dam in 1901 (rkm [river kilometer] 739) and culminating with Hell's Canyon Dam in 1967 (rkm 398). Bull trout Salvelinus confluentus and mountain whitefish Prosopium williamsoni are also native to the Snake River Basin below Shoshone Falls, as are a number of nongame fish species. Nonnative trout, including rainbow trout of hatchery origin and coastal descent, brook trout Salvelinus fontinalis, and brown trout Salmo trutta, were previously introduced in the basin and have established some self-sustaining populations in streams within the study area.

We divided study sites into desert or montane streams by grouping all streams within the major river drainages north of the Snake River (i.e., the Weiser, Payette, Boise, and Big Wood rivers) into the montane category and all the remaining drainages into the desert category. This division corresponds well with differences in geology, vegetation, and precipitation (Orr and Orr 1996). In the montane drainages, the topography is characterized by mountainous terrain typical of the Rocky 


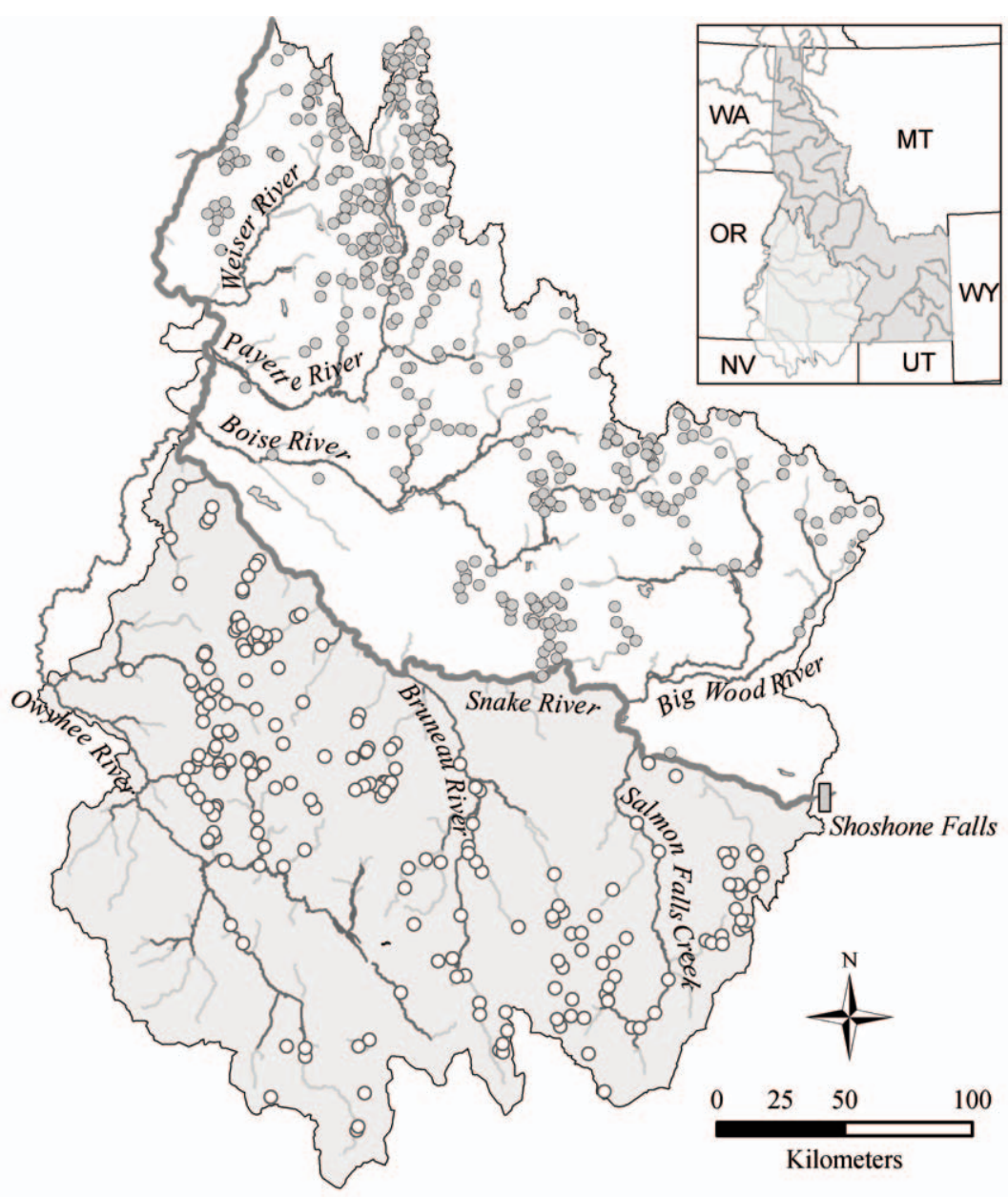

Fig. 1. Location of study sites where redband trout distribution and abundance were sampled in desert (shaded area) and montane (unshaded) portions of the upper Snake River Basin, Idaho.

Mountains, with the geology dominated by the Idaho Batholith and younger Tertiary granitic intrusions. Upland vegetation is largely composed of mixed conifer forest intermixed with sagebrush Artemesia spp. and mesic forbs, with streamside vegetation also consisting of willow Salix spp. Mean annual precipitation in the montane drainages ranges from about $35 \mathrm{~cm}$ at lower elevations to over $125 \mathrm{~cm}$ at higher elevations. In the desert drainages, the landscape is characterized by broken plateaus, barren rocky ridges, cliffs, and deep gulches and ravines within rhyolite and basalt geologic formations. Upland vegetation is dominated by sagebrush and western juniper Juniperus occidentalis, whereas streamside vegetation is dominated by willows and mesic forbs. Mean annual precipi- tation ranges from $<25 \mathrm{~cm}$ at low elevations to $>76 \mathrm{~cm}$ at higher elevations.

\section{METHODS}

Data collection occurred between 1999 and 2005. Spatially balanced, randomly selected study sites from within the historical range of redband trout in the Snake River Basin in Idaho were generated from a standard 1:100,000 hydrography layer, with the help of the Environmental Protection Agency's Environmental Monitoring and Assessment Program. In short, the technique maps two-dimensional space (in our study, a 1:100,000-scale hydrography layer) into one-dimensional space with defined, ordered spatial addresses and then uses 
restricted randomization to randomly order the spaces. Systematic sampling of the randomly ordered spaces results in a spatially balanced sample (Stevens and Olsen 2004). Sampling occurred during base-flow conditions (usually late June to early October) to minimize differences in fish capture efficiency and seasonal changes in stream habitat. For this study, we included only those streams small enough that fish and habitat measurements could be made at the study sites (i.e., $<25 \mathrm{~m}$ average wetted width and $0.7 \mathrm{~m}$ average depth).

\section{Fish Sampling}

At each study site that contained enough water to support fish, we typically determined abundance of salmonids by conducting multipass (2-4-pass) depletion electrofishing $(n=$ 579) with one or more pulsed-DC backpack electrofishers (Smith-Root Model 15-D). Fish were identified, measured to the nearest millimeter (total length $=\mathrm{TL}$ ), weighed to the nearest gram, and released. The few hatchery rainbow trout (all of which were sterile triploids) that we encountered were easy to differentiate from wild redband trout based on fin condition, and these were not included in this study. Block nets were installed at the upper and lower ends of the sites to satisfy the assumption that the fish populations were closed. Depletion sites were typically ( $85 \%$ of the time) $70-120$ $\mathrm{m}$ long $(\bar{x}=88 \mathrm{~m}$, range $20-170 \mathrm{~m})$, with length depending on habitat types and our ability to place block nets. Maximum-likelihood abundance and variance estimates were calculated with the MicroFish software package (Van Deventer and Platts 1989). When all trout were captured on the first pass, we estimated abundance to be the total catch.

Because electrofishing is known to be size selective (Sullivan 1956, Reynolds 1996), trout were separated into 2 length categories $(<100$ $\mathrm{mm}$ TL and $\geq 100 \mathrm{~mm}$ TL), and abundance estimates were made separately for each size group and summed to estimate total abundance. Age-0 fish emerged from the gravel prior to our sampling, and based on previous aging of O. mykiss in Idaho streams (Copeland and Putnam 2008, Schill 2009), they constituted nearly all the fish $<100 \mathrm{~mm}$. Depletions were conducted only for salmonids. For most other species, based on the number of fish observed during electrofishing, we recorded categories of relative abundances that included $0,1-10$,
$10-50$, and $>50$. For smallmouth bass Micropterus dolomieui and northern pikeminnow Ptychocheilus oregonensis, both known predators of salmonids (Eggers et al. 1978, Zimmerman 1999, Fritts and Pearsons 2004), we used the total number of fish caught as an index of abundance.

Snorkeling was performed at sites too large for backpack electrofishing (i.e., 10-25 m wetted width; $n=36$ ), and sampling followed the protocol of Thurow (1994). Snorkeling was not conducted unless visibility was $\geq 2 \mathrm{~m}$. Depending on stream width, 1 to 3 snorkelers attempted to count all salmonids $>100 \mathrm{~mm}$ (TL), binning them into 25 -mm size classes; abundance for other species was recorded as above. Total counts were used as minimum abundance estimates, with no correction for sightability efficiency. From the above electrofishing and snorkeling data, we estimated for each study site the occurrence (presence) and abundance (density) of redband trout.

\section{Habitat Sampling}

Several stream habitat, watershed, and biotic variables were measured to assess their relationship to redband trout occurrence and abundance (Table 1). At each study site, we determined elevation (m) from U.S. Geological Survey (USGS) 1:24,000-scale topographic maps using GPS-acquired Universal Transverse Mercator (UTM) coordinates obtained at the lower end of the reach. Stream order (Strahler 1964) was determined from a $1: 100,000$-scale stream hydrography layer. Gradient (\%) was determined using the software package All Topo Maps Version 2.1 for Windows (iGage Mapping Corporation, Salt Lake City, UT). The distance $(\mathrm{m})$ between the 2 contour lines that bound the study site was traced (average traced distance was about $1 \mathrm{~km}$ ), and gradient was calculated as the elevational increment between those contours divided by the traced distance. Specific conductivity $\left(\mu \mathrm{S} \cdot \mathrm{cm}^{-1}\right)$ was measured with a calibrated, handheld conductivity meter accurate to $\pm 2 \%$.

Ten equally spaced transects were established throughout the sample site from which the remaining measurements took place. Stream-wetted width (m) was calculated from the average of all transect readings. Across the transects, mean water depth was estimated by measuring depth at $1 / 4,1 / 2$, and $3 / 4$ distance across the channel and dividing the sum by 4 
to account for zero depths at the stream margins for trapezoidal-shaped channels (Platts et al. 1983, Arend 1999). From these measurements, we calculated the width:depth ratio. Percent substrate composition was visually estimated as the percentage of stream bottom within $1 \mathrm{~m}$ of each transect that was comprised of silt $(<0.06 \mathrm{~mm})$, sand $(0.06-1.99$ $\mathrm{mm})$, gravel $(2-63 \mathrm{~mm})$, cobble $(64-249 \mathrm{~mm})$, boulder $(250-3999 \mathrm{~mm})$, or bedrock $(>4000$ $\mathrm{mm}$; see Platts et al. 1983). Percent unstable banks and stream shading were also visually estimated within $1 \mathrm{~m}$ of each transect. All ocular estimates were averaged across all transects, yielding an overall mean for each study site.

At a subsample of arbitrarily selected study sites $(n=51)$, electronic data loggers that recorded continuous water temperature $\left({ }^{\circ} \mathrm{C}\right)$ were deployed in the spring and retrieved in the fall in the year in which the site was sampled. Once the data loggers were retrieved, we calculated mean temperature throughout June-August (hereafter termed Temp ${ }_{s m r}$ ). In Idaho, this period typically includes the highest water temperatures experienced by streamdwelling fish. These elevated temperatures have been shown to influence redband trout occurrence and density (Ebersole et al. 2001, Zoellick 2004).

\section{Data Analyses}

Before beginning our analyses, we reduced the number of potential independent variables by postulating which variables might influence redband trout occurrence and abundance. For example, we assumed conductivity might affect the productivity of streams (McFadden and Cooper 1962) and therefore the density of redband trout, but not their occurrence. Streamwetted width was used to represent stream size in our analyses of redband trout occurrence (see Muhlfeld et al. 2001a); but because width was incorporated directly into estimates of redband trout density, stream order was used as an alternate metric of stream size in our analyses of redband trout density. Width:depth ratio was also included in our analyses of redband trout density (Lanka et al. 1987), but not in our analyses of occurrence.

We assumed nonnative trout density might influence redband trout occurrence and density in montane streams (Cunjak and Green 1984), but this variable was excluded from similar analyses in desert streams because the occurrence of nonnative trout in these streams was rare $(<5 \%$ of the study sites). Similarly, the combined relative abundance (i.e., the number caught during sampling) of smallmouth bass and northern pikeminnow was included as an independent variable that might influence redband trout occurrence via predation, but smallmouth bass and northern pikeminnow were rarely sympatric with redband trout. Thus, this variable was excluded from redband trout density analyses and excluded from all analyses of montane streams because of the scarcity of these species in those streams. To further minimize the number of independent variables being analyzed, we only included the 3 substrate categories most likely to influence redband trout occurrence and abundance: silt (as a metric of habitat disturbance), gravel (as a metric of spawning habitat), and cobble/boulder (as a metric of rearing habitat).

We assessed whether any of the biotic and abiotic factors we measured were related to redband trout occurrence and density, separating our analyses into montane streams $(n=$ $342)$ and desert streams $(n=273)$. We first plotted the independent variables against density to look for data abnormalities and to assess whether any parameters appeared to have a nonlinear relationship with density. We especially looked for wedge-shaped (Terrell et al. 1996) or bell-shaped (Isaak and Hubert 2004) distributions of data. No such abnormalities or data patterns were definitive, except for unequal error variance when comparing many of the parameters to redband trout density. We alleviated this abnormality with a $\log _{10}$-transformation of redband trout density for all further analyses. Multicollinearity between independent variables was assessed with Pearson product-moment correlation coefficients $(r)$, but no values were greater than 0.70 , suggesting collinearity was acceptably low in our dataset (Tabachnick and Fidell 1989).

To assess the relationship between environmental conditions and the occurrence of redband trout, we compared the means and $95 \%$ confidence intervals (CIs) of the stream conditions at sites with and without redband trout and formally tested the relationships with logistic regression. A binary dummy variable $(0=$ absent, $1=$ present $)$ was used as the response variable.

To assess the strength of all candidate models, we used Akaike's information criteria 
(AIC), which is an extension of the maximumlikelihood principle with a bias correction term that penalizes for added parameters in the model (Akaike 1973); lower AIC values indicate better-fitting models. Following Burnham and Anderson (2002), we used the bias correction for small sample sizes $\left(\mathrm{AIC}_{c}\right)$, since $n / k<40$ for the full models (where $n$ was the number of study sites and $k$ was the number of parameters in the model), which included intercept and error terms. The most plausible models were judged to be those with $\mathrm{AIC}_{c}$ values within 2.0 of the best model (Burnham and Anderson 2004). We calculated $\mathrm{AIC}_{c}$ weights $\left(w_{i}\right)$ to judge the relative plausibility of each of the most plausible models, and the adjusted $R^{2}$ for discrete models $\left(\tilde{R}^{2}\right.$; Nagelkerke 1991) was used to assess the amount of variation explained by the models. Because $w_{i}$ indicated that no individual model was clearly the best model, we calculated model-averaged parameter estimates and standard errors, which incorporated model uncertainty (Burnham and Anderson 2002) from all the most plausible models to show the direction and strength of the relationships between the parameters and redband trout occurrence and abundance. Only first-order interactions were tested for significance, and none were detected for variables that were included in the best models. We also used logistic regression to relate Temp $_{\text {smr }}$ to redband trout occurrence for the subsample of study sites for which continuous summer water temperature data were available. As above, we separated our analyses into montane $(n=14)$ and desert $(n=37)$ streams.

For the 384 sites where redband trout were present, we assessed the relationships between environmental conditions and redband trout density $\left(\log _{10}\right.$ transformed) using linear regression. We used quantile regression to test for wedge-shaped patterns (Terrell et al. 1996) and quadratic terms to test for bell-shaped patterns (Isaak and Hubert 2004) in the independent variables; but the results were similar and not stronger than linear models, so we present only the linear models. We divided our analyses between desert $(n=176)$ and montane $(n=208)$ streams, used model averaging for parameter estimates and standard errors, and only tested for first-order interactions (none were detected for variables included in the best models). Adjusted $R^{2}$ was used to assess the amount of variation explained by the models. We also used linear regression to relate Temp $_{\text {smr }}$ to redband trout density for the subsample of sites with redband trout presence and water temperature data (montane streams, $n=12$; desert streams, $n=30$ ).

\section{Results}

Of the 615 sites that contained at least one species of fish, redband trout were found at $384(62 \%)$ of the sites, including $176(65 \%)$ of the 273 study sites in desert streams and 208 $(61 \%)$ of the 342 study sites in montane streams. For sites that contained redband trout, mean density was 21 redband trout $\cdot 100 \mathrm{~m}^{-2}(95 \%$ CI 17-26) for desert streams and 11 redband trout $\cdot 100 \mathrm{~m}^{-2}$ (95\% CI 10-13) for montane streams.

Environmental conditions differed substantially between desert and montane streams (Table 1). Desert streams tended to be lower in gradient and elevation, were less shaded by overhead vegetation, had more unstable streambanks, were higher in conductivity and summer water temperature, contained more silt and gravel substrate and less cobble/boulder substrate, and contained fewer nonnative salmonids compared to montane streams. Moreover, within each environmental setting, there were differences in many stream-habitat parameters between sites that did and did not contain redband trout (Table 1). For both desert and montane environments, the occurrence of redband trout tended to increase as the percentage of silt substrate decreased and as the percentage of cobble/boulder substrate increased. In desert streams, the occurrence of redband trout also tended to increase as gradient and stream shading increased; whereas in montane streams, the occurrence of redband trout tended to increase at lower gradients and lower elevations.

\section{Redband Trout Occurrence}

For redband trout occurrence in desert streams, shading was the strongest contributing variable (positive relationship) for all the top logistic regression models (Table 2 ), followed by percentage of fine substrate (negative relationship). Percentage of cobble/boulder substrate (positive relationship) and relative abundance of northern pikeminnow and smallmouth bass (negative relationship) were the next strongest contributing variables. 


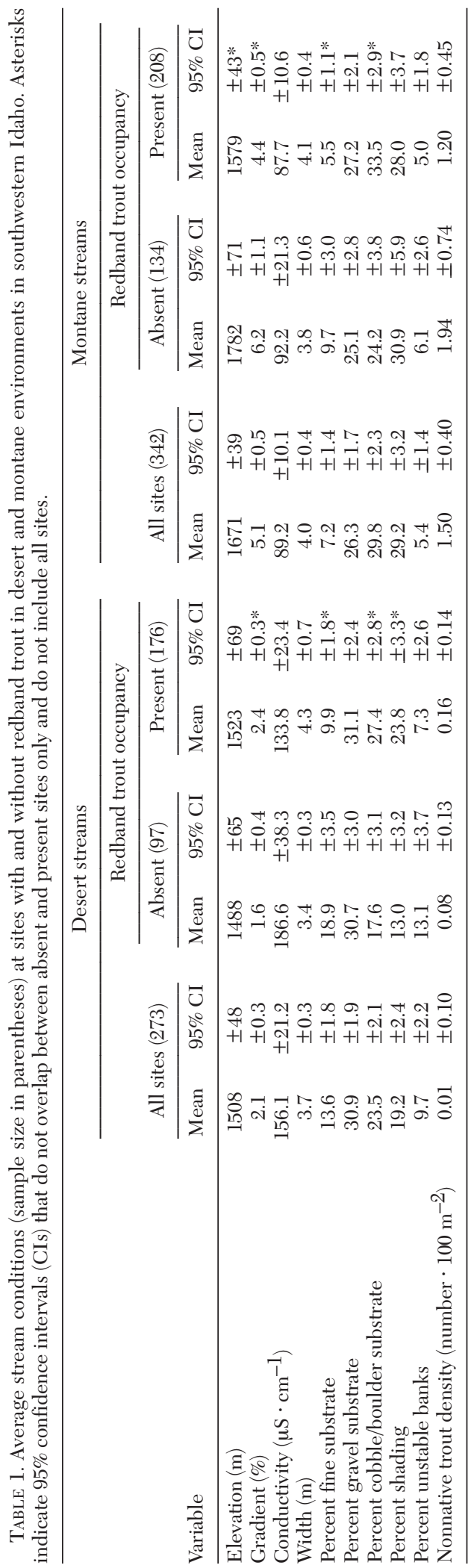

The 7 strongest models, all nearly equal in plausiblility based on $w_{i}$ scores, also contained some combination of the percentage of unstable banks, stream gradient, and site elevation (all negative relationships). The best models explained about $36 \%$ of the variation in the occurrence of redband trout in desert streams.

For redband trout occurrence in montane streams, elevation was the strongest contributing variable (negative relationship) for the top 5 logistic regression models (Table 2), followed by the percentage of cobble/boulder substrate (positive relationship), stream gradient (negative relationship), and stream width (negative relationship). The best models explained about $33 \%$ of the variation in the occurrence of redband trout in montane streams.

Redband trout occurrence was also related to summer stream temperature (Fig. 2). For desert streams, the occurrence of redband trout decreased rapidly at Temp $p_{\mathrm{smr}}>16{ }^{\circ} \mathrm{C}\left(\tilde{R}^{2}=\right.$ $0.39, P=0.01, n=37)$; at $\mathrm{Temp}_{\mathrm{smr}}>20^{\circ} \mathrm{C}$, the probability of redband trout presence was $<0.50$. For montane streams, the occurrence of redband trout increased sharply at $9{ }^{\circ} \mathrm{C}$, and redband trout were always present at Temp $\mathrm{smr}_{\text {sm }}$ $>10{ }^{\circ} \mathrm{C}$. However, Temp ${ }_{\text {smr }}$ was never above $18^{\circ} \mathrm{C}$ for any montane stream, and the sample size for montane streams was much smaller than for desert streams. Thus the model was not statistically significant despite a high $\widetilde{R}^{2}$ value $\left(\widetilde{R}^{2}=0.74, P=0.44, n=14\right)$.

\section{Redband Trout Density}

At desert sites that contained redband trout, all of the most plausible linear regression models relating environmental conditions to redband trout density included stream order (negative relationship) as the strongest contributing variable, followed by stream shading (positive relationship) and percentage of cobble/boulder substrate (positive relationship; Table 3). Most of the most plausible models also included unstable banks (positive relationship) or width:depth ratio (negative relationship) as the next most important variables. The top models explained about $43 \%$ of the variation in redband trout density in desert streams.

For montane streams, stream shading (positive relationship) was the most important variable in the most plausible linear regression models, followed by unstable banks (positive relationship; Table 3). But the best models 
TABLE 2. Model-averaged parameter estimates from the most plausible logistic regression models relating environmental conditions to the occurrence of redband trout in desert ( 15 plausible models) and montane ( 5 plausible models) streams in southern Idaho, including the number of models $(k)$ in which each parameter occurred.

\begin{tabular}{lccc}
\hline Variable & $k$ & Parameter estimate & Standard error \\
\hline Desert & 15 & 0.429 & 0.836 \\
$\quad$ Intercept & 15 & 0.341 & 0.143 \\
Stream shading & 15 & -0.384 & 0.177 \\
$\quad$ Percent fine substrate & 15 & -0.102 & 0.054 \\
$\quad$ Northern pikeminnow/smallmouth & & & \\
$\quad$ bass abundance & 15 & 0.172 & 0.104 \\
Percent cobble/boulder substrate & 8 & -0.186 & 0.126 \\
Unstable banks & 8 & -0.061 & 0.085 \\
Gradient & 8 & -0.001 & 0.001 \\
Elevation & 7 & 0.242 & 0.207 \\
Percent gravel substrate & & & \\
Montane & 5 & 3.130 & 1.019 \\
$\quad$ Intercept & 5 & -0.002 & 0.001 \\
Elevation & 5 & 0.618 & 0.109 \\
Percent cobble/boulder substrate & 5 & -0.145 & 0.039 \\
Gradient & 5 & -0.179 & 0.055 \\
Stream width & 5 & 0.437 & 0.204 \\
Percent gravel substrate & 4 & -0.275 & 0.197 \\
Unstable banks & 2 & 0.335 & 0.222 \\
Percent fine substrate & 2 & -0.318 & 0.142 \\
Stream shading & 1 & & 0.244 \\
Nonnative salmonid abundance & &
\end{tabular}

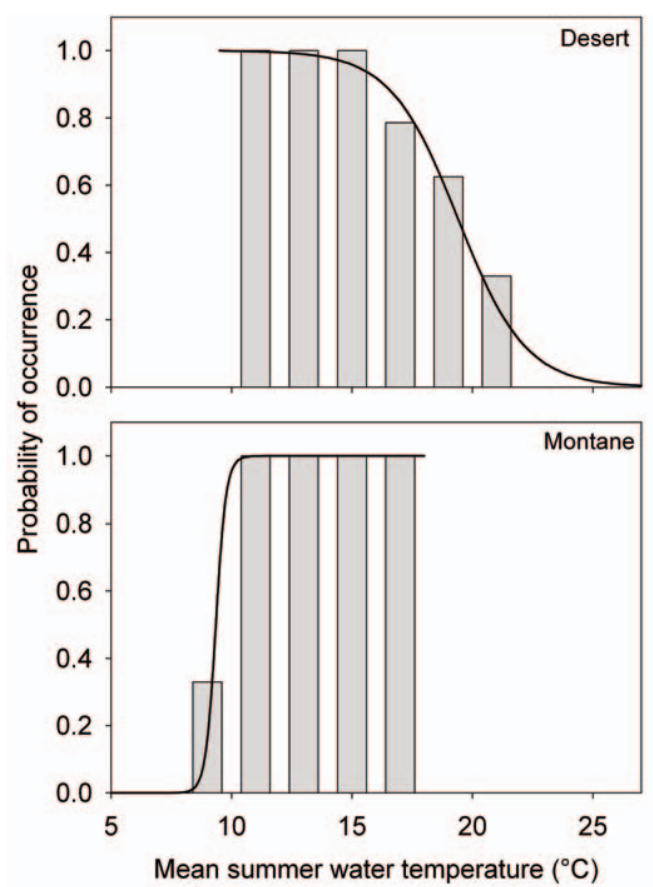

Fig. 2. Observed frequency of occurrence (histograms) and probability of occurrence predicted from logistic regression models (lines) for redband trout against mean summer (Jun-Aug) water temperature in desert and montane streams in southwestern Idaho. The centers of the histograms are the mid-points of the bins used in the frequency distributions. Sample sizes appear within each bar. explained only $17 \%$ of the variation in redband trout density.

For the subsample of sites with temperature data, $\mathrm{Temp}_{\mathrm{smr}}$ was negatively related to redband trout density in desert streams (Fig. 3 ) and explained $41 \%$ of the variation in redband trout density in a least-squares regression model $(y=-0.216 x+1.884 ; n=30 ; P=$ 0.0002). For montane streams, Temp $\mathrm{smr}_{\mathrm{sm}}$ showed no relationship to redband trout density and explained only $3 \%$ of the variation in redband trout density $(y=-0.040 x-0.884 ; n=12 ; P$ $=0.62$.

\section{Discussion}

Our results indicate that summer water temperature was strongly related to the occurrence of redband trout in small- to mediumsized streams (1-25 m wide) in southwestern Idaho. Redband trout were always present when Temp ${ }_{\text {smr }}$ was between $10^{\circ} \mathrm{C}$ and $16{ }^{\circ} \mathrm{C}$, and they were much less likely to be present at temperatures outside this range, regardless of whether the stream was in a desert or montane setting. This pattern may in part be an artifact of our sampling design, since few study sites had Temp ${ }_{\text {smr }}<10^{\circ} \mathrm{C}$ and no montane study sites had Temp $\mathrm{smr}_{\mathrm{s}}>18{ }^{\circ} \mathrm{C}$. Nevertheless, in desert streams, the occurrence of 
TABLE 3. Model-averaged parameter estimates for the most plausible linear regression models relating environmental conditions to the density of redband trout in desert (16 plausible models) and montane (8 plausible models) streams in southern Idaho, including the number of models $(k)$ in which each parameter occurred.

\begin{tabular}{lccc}
\hline Variable & $k$ & Parameter estimate & Standard error \\
\hline Desert & 16 & -1.440 & 0.297 \\
$\quad$ Intercept & 16 & -0.294 & 0.054 \\
Stream order & 16 & 0.248 & 0.051 \\
Stream shading & 16 & 0.097 & 0.038 \\
Percent cobble/boulder substrate & 12 & 0.076 & 0.049 \\
Unstable banks & 12 & -0.005 & 0.004 \\
Width:depth ratio & 8 & 0.135 & 0.072 \\
Percent gravel substrate & 3 & -0.122 & 0.070 \\
Percent fine substrate & 3 & 0.076 & 0.031 \\
Gradient & 3 & 0.001 & 0.000 \\
Conductivity & 1 & 0.000 & 0.000 \\
Elevation & & & \\
Montane & 8 & 1.562 & 1.370 \\
Intercept & 8 & 7.264 & 2.529 \\
Stream shading & 8 & 0.026 & 0.014 \\
Unstable banks & 7 & 0.001 & 0.001 \\
Width: depth ratio & 3 & 0.189 & 0.193 \\
Log ${ }_{10}$ nonnative salmonid abundance & 2 & -0.007 & 0.001 \\
Percent gravel substrate & 2 & -0.122 & 0.156 \\
Elevation & 1 & 0.151 & 0.030 \\
Percent fine substrate & & & \\
\hline
\end{tabular}

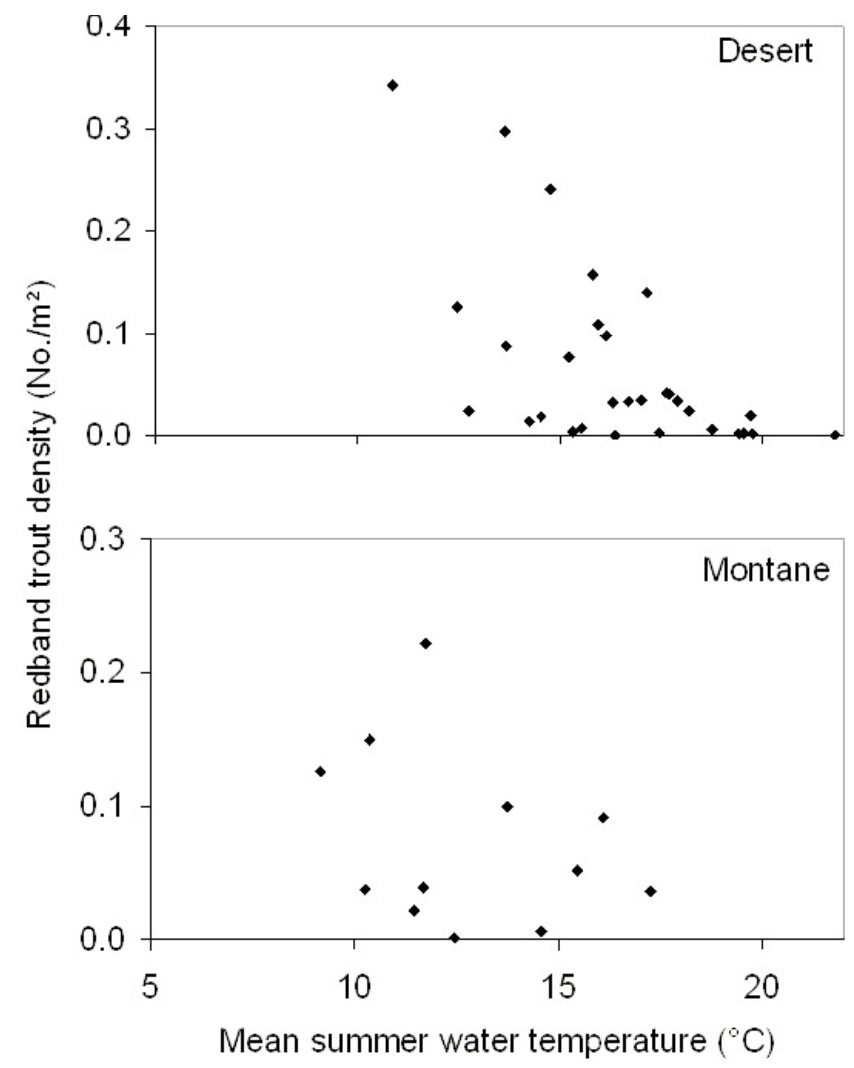

Fig. 3. Scatterplot of mean summer (Jun-Aug) water temperature and redband trout density in desert and montane settings of southwestern Idaho. 
redband trout steadily declined as $\mathrm{Temp}_{\mathrm{smr}}$ increased from $16{ }^{\circ} \mathrm{C}$ (always present) to $22^{\circ} \mathrm{C}$ (present 33\% of the time). A Temp smr $_{\text {s }}$ of about $22{ }^{\circ} \mathrm{C}$ in desert streams corresponded to average daily maximum and summer absolute maximum temperatures of about $26{ }^{\circ} \mathrm{C}$ and $30{ }^{\circ} \mathrm{C}$, respectively. We captured redband trout at 6 sites with maximum water temperatures $>28{ }^{\circ} \mathrm{C}$ and at 2 sites with $>30{ }^{\circ} \mathrm{C}$. These results concur with Zoellick's (1999) finding of redband trout in stream reaches with maximum stream temperatures of $29{ }^{\circ} \mathrm{C}$. These temperatures slightly exceed the thermal tolerance reported for other native salmonids that occupy arid climates in the western United States, such as Bonneville cutthroat trout O. clarkii utah $\left(27^{\circ} \mathrm{C}\right.$; Schrank et al. 2003) and Lahontan cutthroat trout O. c. henshawi $\left(28.5^{\circ} \mathrm{C}\right.$; Dunham et al. 2003).

Only 2 of our 6 sampling events in reaches with maximum temperatures $>28^{\circ} \mathrm{C}$ occurred within 21 days of the warmest day of record; thus we cannot rule out that redband trout may have moved out of our study areas when temperatures were at their maximum and returned when temperatures declined. If redband trout did not leave during the warmest period of record, they may have avoided the elevated temperatures in the warmer sites by seeking thermal refugia (Ebersole et al. 2003) caused by hyporheic upwelling (Ebersole et al. 2001) or simply withstood the stressfully high temperatures through use of heat-shock proteins (Cassinelli 2007). Heat-shock proteins are a crucial cellular response mechanism that repairs the damaging effects of high temperature (reviewed in Feder and Hoffman 1999). These proteins are hypothesized to explain the tolerance of extreme temperatures by other salmonids such as Bonneville cutthroat trout (Schrank et al. 2003). However, regardless of the coping mechanism, our results suggest that summer water temperature constrained the occurrence of redband trout, as has been previously shown (Zoellick 1999, 2004). This conclusion is further supported by the positive relationship we found between shading and the occurrence and density of redband trout in desert streams and by the frequent correlation of shading and summer water temperature ( $\mathrm{Li}$ et al. 1994, Rutherford et al. 1997, Isaak and Hubert 2001).

Our results also suggest that redband trout occurrence in desert streams was negatively related to the combined abundance of northern pikeminnow and smallmouth bass, common predators of salmonids in the western United States (Vigg et al. 1991, Pearsons 1994, Zimmerman 1999, Fritts and Pearsons 2004). There is some evidence that smallmouth bass negatively affect the occurrence of other salmonids in Idaho desert streams (Meyer et al. 2009). Alternatively, the partitioning we observed between redband trout occurrence and these predator species may have been the result of differences in habitat or thermal preferences (Zorn et al. 2002, Torgersen et al. 2006). Regardless of the explanation for partitioning, as climate change results in warmer stream temperatures, predators may invade habitats that were previously too cold to inhabit (Sharma et al. 2007), and higher bioenergetic demands on predators may cause increased consumption of native salmonids (Petersen and Kitchell 2001). Such invasions by predators may further reduce the distribution of redband trout beyond any reduction that warmer water temperature may directly cause.

For the montane streams we studied, lowerelevation sites with lower gradient and more cobble/boulder substrate were more likely to be occupied by redband trout. Cobble and boulder substrate has been linked to rainbow trout habitat preference in both summer (Campbell and Neuner 1985, Baltz et al. 1991) and winter (Campbell and Neuner 1985, Meyer and Griffith 1997, Muhlfeld et al. 2001b) and was one of the top contributing variables in all our modeling efforts, except for the redband trout density models in montane streams. In a study of montane habitats in Wyoming, Kruse et al. (2000) found that Yellowstone cutthroat trout $O$. c. bouvieri were also more likely to occupy lower-elevation, lower-gradient sites. Our finding that redband trout were absent at 2 of the 3 montane streams with $\mathrm{Temp}_{\mathrm{smr}}<10{ }^{\circ} \mathrm{C}$ concurs with Harig and Fausch (2002), who found that reestablishing native cutthroat trout populations was much more likely at streams with $\mathrm{Temp}_{\mathrm{smr}}>10{ }^{\circ} \mathrm{C}$ because successful recruitment was unlikely below this temperature threshold.

In desert streams, temperature was related not only to redband trout occurrence but also to density, with densities approaching zero at $\mathrm{Temp}_{\mathrm{smr}}=26-27^{\circ} \mathrm{C}$. Ebersole et al. (2001) and Zoellick (2004) found similar negative 
relationships between stream temperature and redband trout density in the arid streams they studied. The positive relationship we found between shade and redband trout density in desert streams may reflect the effect stream shade had on summer water temperatures. Density was also related to stream size, as indicated by the negative relationship between density and stream order. This finding concurs with Zoellick and Cade (2006), who concluded that stream shade was positively related to and explained most of the variation in redband trout density in arid streams and that distance from headwaters had a negative relationship with density.

Currently, montane populations of redband trout in our study area rarely experience high summer water temperatures or the abovementioned predators in small- to mediumsized streams. Instead, redband trout density in montane streams was most strongly related to shading, though shading was not related to occurrence. This finding suggests that shading was affecting the habitat quality but not the habitability of montane streams for redband trout by providing benefits other than lowered stream temperature, such as improved cover for trout or increased invertebrate food supply (Glova and Sagar 1994, Saunders and Fausch 2007). For both desert and montane streams, the positive benefit of shading may also have been an indication of lower levels of livestock grazing-a variable we did not measure but which is pervasive in the study area. Livestock grazing reduces stream shading (Knapp and Matthews 1996) and negatively affects trout populations (Clarkson and Wilson 1995, Knapp and Matthews 1996). In Montana, gradient and stream size accounted for much of the variation in redband trout density in montane settings (Muhlfeld et al. 2001a), but these factors were not strongly related to redband trout density in the montane streams in our study area. However, the study by Muhlfeld et al. (2001a) was conducted in a small study area with a small sample size $(n=24)$ and mean stream widths that varied by $<10 \mathrm{~m}$.

Our results suggest that, in general, environmental conditions were more suitable for redband trout in desert streams than in montane streams. Indeed, where redband trout were present, mean densities were almost twice as great in desert streams (21 redband trout . $100 \mathrm{~m}^{-2}$ ) than in montane streams (11 redband trout $\cdot 100 \mathrm{~m}^{-2}$ ). Similarly, Platts and Nelson (1989) found that salmonid biomass was over 3 times higher in Great Basin streams than in Rocky Mountain streams. The higher conductivity in desert streams may have provided better growing conditions and resulted in higher standing stocks, as has been observed in stream-dwelling brown trout (McFadden and Cooper 1962). However, in our study, conductivity was not included in any of the top candidate models relating environmental conditions to redband trout occurrence or density.

A few streams in the montane category were near the valley floors and were thus more desert-like, and a few desert study sites occurred at high elevation and appeared to be more montane-like. However, our categorization of streams as desert or montane appeared to be reasonable since nearly all the environmental parameters we measured were different between desert and montane streams, especially water temperature, gradient, conductivity, percent shading, and nonnative trout density (Table 1). It is therefore not surprising that biotic and abiotic conditions related to the occurrence and abundance of redband trout were also considerably different between these disparate environments, despite their proximity. We deem it unlikely that these differences are inherent between desert and montane populations of redband trout, considering that the 2 populations appear to be similar in terms of temperature tolerance, physiology, and stress response (Cassinelli 2007), as well as genetic population structure (Kozfkay et al. 2007). Rather, the differences are probably a reflection of the phenotypic plasticity of redband trout-a trait that is common among salmonids (e.g., Hutchings 1996, Quinn et al. 1998, Meyer et al. 2003).

A potential limitation of our study is that hatchery rainbow trout of coastal origin have been stocked throughout the study area for nearly a century, and although the Idaho Department of Fish and Game (IDFG) since 2001 has adopted a policy of sterilizing rainbow trout that are stocked in Idaho, we cannot be certain what effect current levels of rainbow trout introgression had on our results. In a companion study conducted by the IDFG genetics lab, a subsample of redband trout $(n=1680)$ collected from 56 of the 384 occupied study sites were fin-clipped and subsequently screened with a combination of 
single nucleotide polymorphisms and microsatellite DNA markers to assess hybridization and population structure. Results indicated that redband trout from $42(75 \%)$ of the 56 study locations in small- to medium-sized streams were pure and that fish from 6 of the 14 sites with hybrids appeared to have relatively low levels $(<20 \%)$ of introgression (Matt Campbell, Idaho Department of Fish and Game, unpublished data). Assuming that a similar level of purity occurred throughout our study area, we believe it is unlikely that introgression introduced a substantial amount of bias to our findings, but we cannot rule out the possibility that some of the relationships we observed between environmental conditions and redband trout occurrence and abundance may have been altered by introgression in our study area. However, considering that redband trout are a subspecies of rainbow trout, we do not believe that introgression would result in substantial changes in habitat preferences, thermal tolerance, or fish behavior. Cassinelli (2007) found that hatchery rainbow trout and redband trout from montane populations could withstand (i.e., grow in and survive) elevated levels of diel-fluctuating water temperatures as well as redband trout from desert populations. Direct comparisons of the habitat preferences and behavior of redband trout, rainbow trout, and their hybrids are needed to better understand what effects introgression may have on native redband trout populations.

Another potential limitation of our study was the inclusion of daytime snorkeling data, which has lower sampling efficiency than multipass depletion electrofishing and therefore may have biased our analyses. However, we believe this bias was minimal. Mullner et al. (1998) estimated that snorkel counts accounted for $65 \%$ of multipass depletion estimates. Thus, the probability that we snorkeled many $100-\mathrm{m}$ reaches and encountered no trout where they were actually present was probably very low and likely would only have occurred where densities were extremely low (in reality, near zero). Therefore, the inclusion of snorkeling data would likely have resulted in almost no bias for our occurrence analyses. Moreover, snorkeling data constituted $<5 \%$ of the redband density dataset, and it is unlikely that a slight bias at $<5 \%$ of our study sites would have changed our conclusions regarding factors related to redband trout density.
Although summer water temperature explained much of the variation in redband trout occurrence and density (except for density in montane streams), at sites with no water temperature data, a substantial portion $(57 \%-83 \%)$ of the total variation in redband trout occurrence or density was left unexplained by the environmental conditions we measured. Other factors that we did not measure may also have been related to redband trout occurrence and density in our study area, such as abundance of pools (Muhlfeld et al. 2001a), invertebrate biomass ( $\mathrm{Li}$ et al. 1994), or overhead cover (Keller and Burnham 1982). However, regardless of what environmental conditions we measured, limiting factors in nature are dynamic and interactive, and rarely does one factor limit a population in a strictly linear manner (Terrell et al. 1996, Zoellick and Cade 2006), especially across vast landscapes, such as in our study (Fausch et al. 1988).

Our finding that environmental conditions related to the occurrence and abundance of redband trout differed between desert and montane streams is important for resource managers who manage these disparate populations occurring in such close proximity to each other. This is especially true in light of potential changes in climate or resource extraction, which could alter future relationships between animals and their environment. For small streams in Idaho, redband trout in arid streams appeared to be restricted by warm summer water temperatures and presence of piscivorous fish. Though these conditions do not appear to currently restrict redband trout in montane streams, ongoing climate change could alter this scenario. Similarly, stream shading appeared to affect habitat quality for redband trout in montane streams, but this variable may ultimately influence redband trout occupancy via its effect on summer stream temperatures. It is important for resource managers to understand the complexities and uncertainties in the relationships between fish and their environment, especially since fish populations are limited by more than the set of environmental variables included in a particular study.

\section{ACKNOWLEDGMENTS}

A number of people assisted with data collection, most notably John Cassinelli, Steve Elle, and Liz Mamer. We are indebted to the 
landowners throughout the Snake River Basin who gave us permission to sample streams on their property, for without their cooperation, this study would not have been possible. The states of Nevada and Oregon generously permitted us access to streams within their jurisdiction. Chris Hirsch and Lance Hebdon provided helpful suggestions on an earlier draft of the manuscript. This project was supported by funds from Federal Aid in Sport Fish Restoration project F-73-R-20 and by the Bonneville Power Administration.

\section{Literature Cited}

AKAIKE, H. 1973. Information theory and an extension of the maximum likelihood principle. Pages 267-281 in B.N. Petran and F. Csaki, editors, International symposium on information theory. 2nd edition. Akadémiai Kiadó, Budapest, Hungary.

Arend, K.K. 1999. Macrohabitat identification. Pages 75-93 in M.B. Bain and N.J. Stevenson, editors, Aquatic habitat assessment: common methods. American Fisheries Society, Bethesda, MD.

BaLtz, D.M., B. Vondracek, L.R. Brown, and P.B. Moyle. 1991. Seasonal changes in microhabitat selection by rainbow trout in a small stream. Transactions of the American Fisheries Society 120:166-176.

Behnke, R.J. 2002. Trout and salmon of North America. The Free Press, New York, NY.

BINNS, N.A. 1982. Habitat quality index procedures manual. Wyoming Game and Fish Department, Cheyenne, WY. 209 pp.

Burnham, K., AND D.R. ANderson. 2002. Model selection and multimodel inference: a practical informationtheoretical approach. 2nd edition. Springer-Verlag, New York, NY.

. 2004. Multimodel inference: understanding AIC and BIC in model selection. Sociological Methods and Research 33:261-304.

Campbell, R.F., and J.H. Neuner. 1985. Seasonal and diurnal shifts in habitat utilized by resident rainbow trout in western Washington Cascade mountain streams. Pages 39-48 in F.W. Olson, R.G. White, and R.H. Hamre, editors, Symposium on small hydropower and fisheries. American Fisheries Society, Western Division and Bioengineering Section, Bethesda, MD.

CASSINELLI, J. 2007. Effects of water temperature on growth and physiology of redband trout (Oncorhynchus mykiss gairdneri) from selected Idaho streams. Master's thesis, University of Idaho, Moscow, ID. 135 pp.

Chisholm, I.M., AND W.A. Hubert. 1986. Influence of stream gradient on standing stock of brook trout in the Snowy Range, Wyoming. Northwest Science 60: 137-139.

Clarkson, R.W., and J.R. Wilson. 1995. Trout biomass and stream habitat relationships in the White Mountains area, east-central Arizona. Transactions of the American Fisheries Society 124:599-612.

Copeland, T., and S. Putnam. 2008. Idaho steelhead monitoring and evaluation studies. Idaho Department of Fish and Game Annual Report, Number 08-05. Boise, ID.
CunjaK, R.A., and J.M. Green. 1984. Species dominance by brook trout and rainbow trout in a simulated stream environment. Transactions of the American Fisheries Society 113:737-743.

Dunham, J., R. Schroeter, and B. Rieman. 2003. Influence of maximum water temperature on occurrence of Lahontan cutthroat trout within streams. North American Journal of Fisheries Management 23: 1042-1049.

Ebersole, J.L., W.J. Liss, and C.A. Frissell. 2001. Relationship between stream temperature, thermal refugia and rainbow trout Oncorhynchus mykiss abundance in arid-land streams in the northwestern United States. Ecology of Freshwater Fish 10:1-10. 2003. Cold water patches in warm streams: physicochemical characteristics and the influence of shading. Journal of the American Water Resources Association 39:355-368.

Eggers, D.M., N.W. Bartoo, N.A. Rickard, R.E. Nelson, R.C. Wissmar, R.L. Burgner, and A.H. Devol. 1978. The Lake Washington ecosystem: the perspective from the fish community production and forage base. Journal of the Fisheries Research Board of Canada 35:1553-1571.

Fausch, K.D., C.L. Hawkes, and M.G. Parsons. 1988. Models that predict standing crop of stream fish from habitat variables: 1950-1985. General Technical Report PNW-GTR-213. U.S. Forest Service, Pacific Northwest Research Station, Portland, OR.

Feder, M.E., And G.E. Hoffman. 1999. Heat-shock proteins, molecular chaperones, and the stress response: evolutionary and ecological physiology. Annual Review of Physiology 61:243-282.

FritTs, A., AND T.N. PEARSONs. 2004. Effects of predation by nonnative smallmouth bass on native salmonid prey: the role of predator and prey size. Transactions of the American Fisheries Society 135:853-860.

GLOva, G.L., AND P.M. Sagar. 1994. Comparison of fish and macroinvertebrate standing stocks in relation to riparian willows (Salix spp.) in three New Zealand streams. New Zealand Journal of Marine and Freshwater Research 28:255-266.

Harig, A.L., AND K.D. Fausch. 2002. Minimum habitat requirements for establishing translocated cutthroat trout populations. Ecological Applications 12:535-551.

Huston, M.A. 2002. Introductory essay: critical issues for improving predictions. Pages 7-21 in J.M. Scott, P. Heglund, M. Morrison, J. Haufler, M. Raphael, W. Wall, and F. Samson, editors, Predicting species occurrences: issues of accuracy and scale. Island Press, Washington, DC.

Hutchings, J.A. 1996. Adaptive phenotypic plasticity in brook trout, Salvelinus fontinalis, life histories. Ecoscience 3:25-32.

IsaAK, D.J., And W.A. Hubert. 2004. Nonlinear response of trout abundance to summer stream temperatures across a thermally diverse montane landscape. Transactions of the American Fisheries Society 133: 1254-1259.

. 2001. A hypothesis about factors that affect maximum summer stream temperatures across montane landscapes. Journal of the American Water Resources Association 37:351-366.

Keller, C.R., AND K.P. BuRnham. 1982. Riparian fencing, grazing, and trout habitat preference on Summit Creek, Idaho. North American Journal of Fisheries Management 2:53-59. 
KNaPp, R.A., AND K.R. MatThews. 1996. Livestock grazing, golden trout, and streams in the Golden Trout Wilderness, California: impacts and management implications. North American Journal of Fisheries Management 16:805-820.

KozeL, S.J., AND W.A. HubERT. 1989. Factors influencing the abundance of brook trout Salvelinus fontinalis in forested mountain streams. Journal of Freshwater Ecology 5:113-122.

Kozfkay, C.C., M.R. Campbell, D. Schill, K.A. Meyer, AND B. ZoELLICK. 2007. Evaluating genetic diversity and genetic structure of interior redband trout in the environmental extremes of Idaho. Pages 154-159 in R.F. Carline and C. LoSapio, editors, Proceedings of Wild Trout IX Symposium: sustaining wild trout in a changing world. West Yellowstone, MT.

Kruse, C.G., W.A. Hubert, and F.J. Rahel. 2000. Status of Yellowstone cutthroat trout in Wyoming waters. North American Journal of Fisheries Management 20:693-705.

LANKA, R.P., W.A. Hubert, and T.S. Wesche. 1987. Relations of geomorphology to stream habitat and trout standing stock in small Rocky Mountain streams. Transactions of the American Fisheries Society 116: 21-28.

Li, H.W., G.A. Lambert, T.N. Pearsons, C.K. Tait, J.L. LI, AND J.C. BuCKHOUSE. 1994. Cumulative effects of riparian disturbances along high desert trout streams of the John Day Basin, Oregon. Transactions of the American Fisheries Society 123:627-640.

McFadden, J.T., AND E.L. CoOper. 1962. An ecological comparison of six populations of brown trout (Salmo trutta). Transactions of the American Fisheries Society $91: 53-62$.

Meyer, K.A., F.S. Elle, and J.A. Lamansky, Jr. 2009. Environmental factors related to the distribution, abundance, and life history characteristics of mountain whitefish in Idaho. North American Journal of Fisheries Management 29:753-767.

MeYer, K.A., AND J.S. GRIFFith. 1997. Effects of cobbleboulder substrate configuration on winter residency of juvenile rainbow trout. North American Journal of Fisheries Management 17:77-84.

Meyer, K.A., D.J. Schill, F.S. Elle, and J.A. Lamansky, JR. 2003. Reproductive demographics and factors that influence length at sexual maturity of Yellowstone cutthroat trout in Idaho. Transactions of the American Fisheries Society 132:183-195.

Muhlfeld, C.C., D.H. BennetT, and B. Marotz. 2001a. Summer habitat use by Columbia River redband trout in the Kootenai River drainage, Montana. North American Journal of Fisheries Management 21:223-235.

.2001b. Fall and winter habitat use and movement by Columbia River redband trout in a small stream in Montana. North American Journal of Fisheries Management 21:170-177.

MulLner, S.A., AND W.A. HubERT. 1998. Snorkeling as an alternative to depletion electrofishing for estimating abundance and length-class frequencies of trout in small streams. North American Journal of Fisheries Management 18:947-953.

NAGELKERKE, N.J.D. 1991. A note on a general definition of the coefficient of determination. Biometrika 78: 691-692.

OrR, E.L., AND W.N. ORR. 1996. Geology of the Pacific Northwest. McGraw-Hill, New York, NY.
Pearsons, T.N. 1994. Formation and maintenance of fish assemblages in a high desert Oregon stream. Doctoral dissertation, Oregon State University, Corvallis, OR.

Petersen, J.H., AND J.F. Kitchell. 2001. Climate regimes and water temperature changes in the Columbia River: bioenergetic implications for predators of juvenile salmon. Canadian Journal of Fisheries and Aquatic Sciences 58:1831-1841.

Platts, W., W. Megahan, and G. Minshall. 1983. Methods for evaluating stream, riparian, and biotic conditions. Gen. Tech. Rep. INT-138, USDA Forest Service, Ogden, UT.

PlatTS, W.S., AND R.L. Nelson. 1989. Stream canopy and its relationship to salmonid biomass in the Intermountain West. North American Journal of Fisheries Management 9:446-457.

Quinn, T.P., E. Graynoth, C.C. Wood, and C.J. Foote. 1998. Genotypic and phenotypic divergence of sockeye salmon in New Zealand from their ancestral British Columbia populations. Transactions of the American Fisheries Society 127:517-534.

Reynolds, J.B. 1996. Electrofishing. Pages 221-254 in B. Murphy and D. Willis, editors, Fisheries techniques. 2nd edition. American Fisheries Society, Bethesda, MD.

Rutherford, J.C., S. Blackett, C. Blackett, L. Saito, and R.J. DaVIES-Colley. 1997. Predicting the effects of shade on water temperature in small streams. New Zealand Journal of Marine and Freshwater Research 31:707-721.

SAUNDERS, W.C., AND K.D. FAusCH. 2007. Improved grazing management increases terrestrial invertebrate inputs that feed trout in Wyoming rangeland streams. Transactions of the American Fisheries Society 136: 1216-1230.

Schill, D.J. 2009. Population studies of desert redband trout. Doctoral dissertation. University of Idaho, Moscow, ID. $180 \mathrm{pp}$.

Schrank, A.J., F.J. Rahel, and H.C. Johnstone. 2003. Evaluating laboratory-derived thermal criteria in the field: an example involving Bonneville cutthroat trout. Transactions of the American Fisheries Society $132: 100-109$.

Sharma, S., D.A. Jackson, C.K. Minns, and B.J. Shuter. 2007. Will northern fish populations be in hot water because of climate change? Global Change Biology 13:2052-2064.

Stevens, D.L., JR., and A.R. Olsen. 2004. Spatially balanced sampling of natural resources. Journal of the American Statistical Association 99:262-278.

Strahler, A.N. 1964. Quantitative geomorphology of drainage basins and channel networks. Section 4-2 in V.T. Chow, editor, Handbook of applied hydrology. McGraw-Hill, New York, NY.

Sullivan, C. 1956. The importance of size grouping in population estimates employing electric shocking. Progressive Fish-Culturist 18:188-190.

Tabachnick, B.G., AND L.S. Fidell. 1989. Using multivariate statistics. 2nd edition. Harper Collins, New York, NY.

Terrell, J.W., B.S. Cade, J. Carpenter, and J.M. ThompSON. 1996. Modeling stream fish habitat limitations from wedge-shaped patterns of variation in standing stock. Transactions of the American Fisheries Society 125:104-117.

Thurow, R.F. 1994. Underwater methods for study of salmonids in the Intermountain West. General 
Technical Report, INT-GTR-307, USDA Forest Service, Logan, UT.

Thurow, R.F., D.C. Lee, and B.E. Rieman. 1997. Distribution and status of seven native salmonids in the Interior Columbia River Basin and portions of the Klamath River and Great basins. North American Journal of Fisheries Management 17:1094-1110.

Torgersen, C.E., C.V. BaXter, H.W. Li, and B.A. McInTOSH. 2006. Landscape influences on longitudinal patterns of river fishes: spatially continuous analysis of fish-habitat relationships. Pages 473-492 in R.M. Hughes, L. Wang, and P.W. Seelbach, editors, Landscape influences on stream habitats and biological assemblages. American Fisheries Society, Symposium 48, Bethesda, MD.

[USOFR] United States Office of the Federal RegISTER. 1995. Endangered and threatened wildlife and plants; a 90-day finding for a petition to list desert redband trout in the Snake River drainage above Brownlee Dam and below Shoshone Falls as threatened or endangered. Federal Register 60 (187 [20 September 1995]):49819-49821.

Van Deventer, J., and W.S. Platts. 1989. Microcomputer software system for generating population statistics from electrofishing data—user's guide for MicroFish 3.0. USDA Forest Service General Technical Report INT-254.

Vigg, S., T. Poe, L. Prendergast, and H. Hansel. 1991. Rates of consumption of juvenile salmonids and alternative prey fish by northern squawfish, walleyes, smallmouth bass, and channel catfish in John Day Reservoir, Columbia River. Transactions of the American Fisheries Society 120:421-438.

Zimmerman, M.P. 1999. Food habits of smallmouth bass, walleyes, and northern pikeminnow in the lower Columbia River Basin during outmigration of juvenile anadromous salmonids. Transactions of the American Fisheries Society 128:1036-1054.

ZoeLLiCK, B.W. 1999. Stream temperatures and the elevational distribution of redband trout in southwestern Idaho. Great Basin Naturalist 59:136-143.

2004. Density and biomass of redband trout relative to stream shading and temperature in southwestern Idaho. Western North American Naturalist 64:18-26.

Zoellick, B.W., AND B.S. CADE. 2006. Evaluating redband trout habitat in sagebrush desert basins in southwestern Idaho. North American Journal of Fisheries Management 26:268-281.

Zorn T.G., P.W. SeElbach, AND M.J. Wiley. 2002. Distributions of stream fishes and their relationship to stream size and hydrology in Michigan's lower peninsula. Transactions of the American Fisheries Society 131:70-85.

Received 30 January 2009 Accepted 6 October 2009 